\title{
EMPLOYEE PERCEPTIONS ON THE IMPACT OF REAL OPTIONS ON FIRM PERFORMANCE: AN EMPIRICAL STUDY CONDUCTED IN INDIA
}

\author{
Anjit MATHUR \\ Rahul SHRESTH \\ Avantika TOMAR \\ Indian Institute of Management Calcutta
}

\begin{abstract}
Dynamic capabilities are the organizational and strategic routines by which firms achieve new resource configurations as markets emerge, collide, split, evolve, and die (Eisenhardt \& Martin, 2000). Human resources are also a source of dynamic capability. Market uncertainties can make return on investments in human assets uncertain and risky. Investments in human resources can be designed to protect the firm's human assets from risks and to get returns that are also created by uncertainties. Real options theory deals with managing investments in human assets under uncertainty for creating sustainable value for firms in dynamic environments. This study seeks to investigate the employee perceptions on how real options affect firm-level performance and develop a causal model that links the real options that firms use to exploit uncertainties with the firm-level performance outcomes. The concept of HR options was operationalized based on the study by Sanyal and Sett (2009) in the Indian IT industry context. The scales measuring the use of HR options and performance of the firms were validated in the context of all industries. Thereafter, a questionnaire based field survey was carried out obtaining the responses from the employees of various firms in India. As per the employee survey, the use of HR options mediates the effect of environmental uncertainties on performance of their firms. Also, firms using real options show superior performance with respect to their counterparts.
\end{abstract}

Key words: Real options, relative firm performance, firm performance improvement, environmental uncertainties, skills enhancement options, productivity enhancement options.

\section{INTRODUCTION}

Bhattacharya and Wright (2005) have analysed the uncertainties faced by a firm's human assets by type of uncertainties, and the sources of uncertainty. They identified three types of uncertainties faced by human resources of a firm - uncertainties of return, uncertainties of volume and combination, and uncertainties of costs. They argue that the sources of these uncertainties could be the market, the firm itself or the individual employees. In order to combat these uncertainties, firms like to exercise certain options. Options are mainly understood as financial in nature. However, in order to offset the impact of uncertainties faced by a firm's human assets, real options are needed. Exogenous changes like technological developments, product and process innovations, shift in consumer preferences, competitive moves by the rivals, and so on may also call for a change in firm strategy. Such changes in strategy need a different configuration of human assets to be deployed for the implementation of this strategy.

An option is defined by returns that are nonlinear and contingent on the stochastic state of the world (Kogut \& Kulatilaka, 2001). A real option is an investment in physical and human assets that provides the opportunity to respond to future contingent events. A real option is thus, technically defined by an investment decision that is characterized by uncertainty, the provision of future managerial discretion to exercise at the appropriate time (McGrath et al., 2004). 
Real options can be defined as the option to defer, the option to stage and sequence investment, the option to alter operating scale, the option to abandon, the option to switch inputs or outputs, growth options, and multiple interacting options (Trigeorgis, 1993). Flexibility options - to alter scale of operations and/or switch process inputs or outputs, are built into the initial design (e.g., flexible manufacturing system; recruitment of multi-skilled workforce) when uncertainties in factor or productmarkets are expected. Discretionary investments in R\&D and development of new skills for exploiting future opportunities are regarded as growth and learning options (Sanyal \& Sett, 2009). Real options theory contends that options are valuable because they bestow on the firm's managers the flexibility to proactively adapt their future actions, in response to altered internal or external environmental conditions and thereby help the firm to gain competitive advantage over its rivals that do not have such options (Kogut \& Kulatilaka, 2001). Disregarding the uncertainties surrounding the human assets is likely to lead to overvaluation of such assets and to underestimation of the role of investments in human assets in creating market value for the firm (Bhattacharya \& Wright, 2005).

HR options are "investments in the human capital pool of an organization that provide the capability to respond to future contingent events" (Bhattacharya \& Wright, 2005). According to this definition, Human Resource Options are a sub-set of real options. A firm's investment in HR options is made through HR practices that can build a human resource capability, comprising skills and behavioural repertoires of employees, to flexibly respond to future uncertain events (Bhattacharya \& Wright, 2005; Wright \& Snell, 1998). To have no option value (and thus not represent a real option), an investment would have to meet two tests: (1) the resource in question would generate no future choices, and (2) the resource would allow no "preferential access to future opportunities" (Bowman \& Hurry, 1993: 762).

As managers expect environmental uncertainties due changes in technology, competitor behaviour, consumer preferences, etc., they tend to create options for alternate deployment of their human resources, by promoting skill and behavioural flexibilities as well as in HR practices flexibility (Bhattacharya and Wright, 2005). These capabilities enable the firm for superior operational and financial performance. HR Options also empower the employees with skills as well as behavioural routines that are required to serve not only the existing customers and product markets using the existing processes but also the new customers and product market segments that may need use of new processes to give the firm a competitive advantage. In other words, HR options mediate the effect of environmental uncertainties on firm performance.

This study attempts to establish some of the above theories and hypotheses as understood by the employees. Several existing studies have used the top management lens to hypothesize these relationships. However, literature does not discuss the importance of acceptance of these changes by the employees which is imperative for superior firm performance. Therefore, the respondents of this have been employees and their perceptions regarding the mediating effect of HR options on the relationship between environmental uncertainties and firm level performance have been studied.

\section{LITERATURE REVIEW}

\section{Environmental uncertainties and Human Resource Interventions}

Fluctuations in demand for the firm's existing product affect the quantity while market demand for new, or improved, or substitute products which need different production processes affect both quantity and nature of human capital needed to be deployed by the firm (Sanyal and Sett, 2009). These changes can make some of the existing resources redundant (in terms of skills and/or number) and call for new skills and competencies. Increasing demand for a new skill which is in short supply raises its market price creating uncertainties of return, irrespective of whether the firm can meet such demands through internal or external labour market. At employee level, the value of a firm's current human assets can get impaired if the employees do not quickly pick up the new competencies required in the changed scenario due to their lack of learning abilities, motivation, or due to resistance to such changes. Another way in which the value of the firm's human assets may get eroded is due to uncertain and declining employee productivity arising out of gradual disengagement of the employees with the strategic goals of the firm. Declining employee productivity may happen both at individual 
and collective levels, requiring appropriately different HR interventions. For the purpose of this study, we have termed these dynamisms as employee skills related uncertainty.

When a firm offers a portfolio of products that requires different production processes and correspondingly, different configurations of skills, it is exposed to labour demand and supply uncertainty. The firm may face surplus/shortage of persons with a given skill at a given location, or division, or unit of the firm. Labour demand and supply uncertainty implies market demands shifting in terms of product-mix calls for changing the skill-mix of people engaged in production of such product portfolios. This may arise also from a firm's endogenous actions like technological upgradation and changes in product offerings to exploit market opportunities or to improve profitability.

Skill and Productivity Enhancement HR Options: Like in the case of a market, firm induced uncertainties also call for numerical and functional flexibilities of human resources of the firm. Employees can create labour demand and supply uncertainty of skills available to the firm at any given point in time by way of fluctuating levels of absenteeism due to whatever reasons, unforeseen exit of a large number persons belonging to a particular skill category, and so on. HR practices such as team based working, existence of adequate and scalable training facilities, and institutional culture of forming task based temporary project teams can enable the organisation to manage such variations (Youndt et al., 1996). Similarly, practices like job rotation, periodic transfers of employees across departments, employment of temporary or part-time workers to absorb temporary increases in workload, creating a buffer through additional bench strength are becoming popular now. From the above discussion it is clear that under conditions of labour demand and supply uncertainty, the HR options that the firm uses relate to capabilities to vary skill and productivity in human resources (e.g., engagement of temporary workforce), and to switch from one skill to another depending on the change in demand-mix (Sanyal \& Sett, 2009).

Similarly, volatilities in revenue can be due to product market demand, economic downturn, intensified product market competition, and so on. Cost related uncertainties arise when a firm's input costs (e.g., employment costs) are high and fixed but its revenues are volatile. At firm level, high debtequity ratio, large sunk cost accompanied by unutilised capacity of fixed assets, etc tend to make the firm's cost structure inherently rigid. "Similarly, hiring a large permanent workforce and paying them fixed salaries above the market rate and offering them liberal fringe benefits (including postretirement benefits) may also make the firm's cost structure rigid and uncompetitive, particularly if the firm is not able to extract above average economic returns (e.g., higher employee productivity) from such investments. Rigid cost structure makes the profitability of the firm highly vulnerable to even relatively small increases in input costs like the periodic salary increases of permanent workforce" (Sanyal \& Sett, 2009). HR practices that help improve labour productivity also help to reduce unit labour cost; but they should be treated as a separate category coming under productivity related HR options. The point of consideration here is those specific HR practices that directly contribute towards financial flexibility of the firm (Atkinson, 1984). Bhattacharya and Wright (2005) also argue that performance based incentive plans at firm or unit level generate options to alter costs.

\section{Options}

Options fall into two basic categories: incremental options and flexibility options (Sharp, 1991). Incremental options take the form of simple calls and puts. Strategic change occurs when flexibility options (i.e., choices to switch investment streams) are exercised. Organizations holding better developed bundles of options will expand more aggressively in growing markets and economic upturns, and they will persist longer in difficult markets and economic down- turns, than competitors holding less developed option bundles. When managers sense high perceived environmental uncertainty (Bowman \& Harry, 1993), they will strive to hold options open, reducing potential losses as much as possible. When managers perceive low environmental uncertainty, they will be motivated to strike options, thus earning gains in terms of growth and profits. Given realistic perceptions of environmental uncertainty, organizations that hold options during unstable periods and strike options in stable periods will show superior long-term growth and profit performance compared to organizations exhibiting other types of investment behavior (Bowman \& Harry, 1993). 

Financial Options

The most well known form of options is a financial option which is a contract written to create right to purchase (or sell) a publicly traded financial asset (e.g., stocks, bonds, currency) at a predetermined price, by or on a certain date, without any obligation to buy (or sell). Option holder creates this discretionary right in his favour by paying a price (option premium), which is his option investment, to the seller. Financial theory of real options derives its heuristics of investing in exploratory search by inferring future value of today's investments from market prices (Kogut \& Kulatilaka, 2001). Firms invest in physical and human assets which are an act of incurring an immediate cost in the expectations of creating future revenue streams. Most of these investments in real assets share three important characteristics in varying degrees: a) irreversibility (initial cost cannot be partly or fully recovered should you change your mind); b) uncertainty (over the future rewards from the investment); and c) timing (you can postpone action to get uncertainty resolved at least partially) (Dixit \& Pindyck, 1994). With financial options, the containment of downside loss typically is a function of abandonment, or, as it is usually described, expiration in the face of a decision not to exercise the option (McGrath et al., 2004).

\section{Real Options}

The real options way of thinking expands the vision and alternatives considered in strategy creation, and the real options tool kit translates strategic vision into a tactical investment plan (Amram \& Kulatilaka, 1999). It gives the managers a way of thinking about how to create value from uncertainty and how to identify the risks and potential pitfalls of the complex contingent business opportunities that are arising in rapidly changing markets. In a narrow sense, the real options approach is the extension of financial option theory to options on real (non-financial) assets (Amram and Kulatilaka, 1999). Real options are up-front investments that allow management to capitalize on favourable opportunities and mitigate downside risks by proactively managing uncertainty over time in a flexible manner rather than by trying to avoid uncertainty (Cyert and March, 1963). Real options literature identifies different classes of real options that firms can use to address the various types of uncertainties they face (Trigeorgis, 2001). Options to defer, stage, or abandon are typically resorted to in cases involving large investments under uncertainty. Many scholars in management literature have seen strategy through the option lens as a process of organisational resource-investment choices, or options (Bowman and Hurry, 1993; Kogut, 1991; Myers, 1977; 1984).

\section{HR Options}

Firms today need to possess organisational ambidexterity that is defined as “an organisation's ability to be aligned and efficient in its management of today's business demands while simultaneously being adaptive to changes in the environment" (Raisch and Birkinshaw, 2008: 378). It is required to maintain a dynamic fit between its supply of human capital and the needs of its changing strategic imperatives. A firm's investment in HR options is made through HR practices that can build a human resource capability, comprising skills and behavioural repertoires of employees, to flexibly respond to future uncertain events (Bhattacharya and Wright, 2005; Wright and Snell, 1998). HR practices represent firm capabilities that create value for the firm by developing enabling human skills and behaviour. These HR practices and processes are to be regarded as dynamic capabilities of the firm (Bowman and Hurry, 2000; Teece et al., 1997) that have option value (Kogut and Kulatilaka, 2001). At this stage we must state that many HR practices (e.g., recruitment tests for technical skills; training on existing skills) that do not address the issue of management of uncertainty do not possess any option characteristics and hence, do not qualify as HR options (Sanyal \& Sett, 2009). Like other investments under uncertainty, a firm must choose among the alternatives which capabilities to invest in based upon market value of such capabilities.

Examples of HR Options: Employee selection that emphasizes cognitive skills and learning abilities rather than narrow functional skills required by current jobs have been found to be associated with adaptable employee skills and behaviours (Snow and Snell, 1993; Wright et al., 1995; Youndt et al., 1996). Comprehensive training programmes that put premium on development of new skills and learning abilities have been found to enhance organisational flexibility by building broader repertoires 

Development oriented employee performance management systems that values and rewards not only current performance but also discretionary behaviour, new skill acquisition, adaptability, or development of competencies required for the future have been found to be effective in fostering learning and motivating employees to acquire new skills and behaviours (Pfeffer, 1998). Career development policies that encourage growth of firm specific skills and behavioural repertoires and put premium on acquisition of such skills by the employees can act as a prime mover in continuous capability renewal and development process. Skill-based pay helped in multi-skilling of employees (Delery and Doty, 1996).

Similarly, above average pay has been found to be associated with higher employee productivity and lower turnover rate (Arthur, 1994; Becker and Huselid, 1998). Similarly, higher employee benefits have also been associated with lower turnover (Arthur, 1994). Financial incentive plans like groupbased performance pay has been found to lead to both higher productivity and longer retention (Becker and Huselid, 1998; Huselid, 1995; MacDuffie, 1995). Career growth opportunities within the organisation, and merit and performance based promotions not only lead to higher efficiency but also higher employee motivation and retention (Becker and Huselid, 1998). Employee participatory practices like quality circles and team-based work design have been seen to contribute towards higher productivity and retention (Arthur, 1994). Existence of effective employee voice systems like information sharing, grievance redressal system or suggestion scheme have been found to be associated with higher employee morale, productivity, and lower turnover rate (Arthur, 1994; Becker and Huselid, 1998).

\section{Firm Performance}

For the purpose of this study, firm performance has been classified as the operational and financial performance of the firm with respect to its competitors i.e. in the industry in which it operates; this has been termed as Relative Performance. Relative performance of the firm includes the groth of its sales revenue, profitability (Profits/Sales), operating cost efficiency (total operating costs/total sales) and growth of market share - all these have been used as a proxy for firm's relative performance (Sanyal $\&$ Sett, 2009). A second metric for firm's operational and financial performance used in this study has Performance Improvement comprising of customer satisfaction level, efficiency of operations, employee productivity, ability to meet customer needs in terms of quality, cost and delivery schedule, successful launch of new products/services and ability to attract and retain customers - all over the past years (Bhattacharya and Wright, 2005; Wright and Snell, 1998)

\section{Hypotheses and Model}

Based on the discussion of the literature above, the following figure sums up the hypothesized causal model:

Figure 1: Hypothesized Causal Model

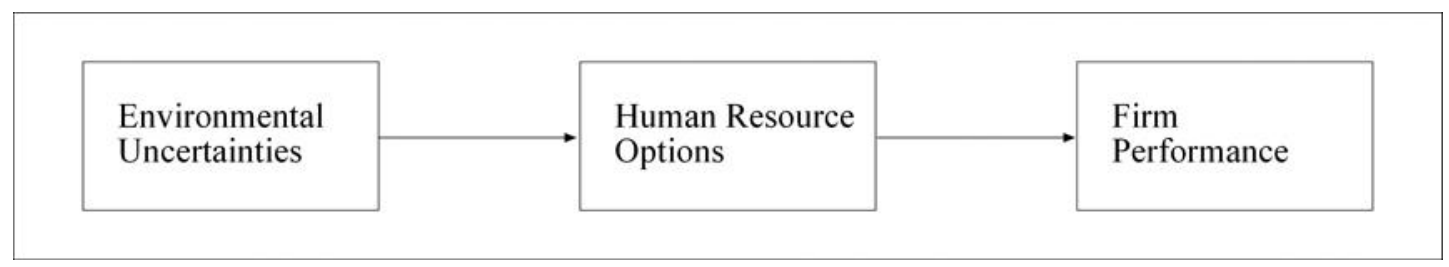

The hypotheses for this study are as follows:

1. Employees can perceive the mediating effect of HR options on the relationship between environmental uncertainties on performance of their firms.

\section{Employees perceive the positive effect of using HR option on firm performance.}

Environmental Uncertainties comprise of 'employee skills related' and 'labour demand and supply' uncertainties. Human resource options for the purpose of this study comprise 
Journal of Glopal Strategic Management | V. 6 | N. 2 | 2012-December | isma.info |140-153 DOI: 10.20460/JGSM.2012615781 of skilt entrancement and productivity enhancement options. Firm performance comprises of 'relative performance' and 'performance improvement'. In order to measure each of these constructs (latent variables), the following questionnaire instrument was used. All the three constructs mentioned in Figure 1 are two-dimensional scales; the details of dimensions with their respective indicators and their measurement have been stated subsequently.

Table 1: Survey Questionnaire

\begin{tabular}{|c|c|c|}
\hline \multirow{7}{*}{$\begin{array}{l}\text { Section } 1 \text { - Fact } \\
\text { Sheet }\end{array}$} & S. No. & Items \\
\hline & 1 & Industry within the Service Sector \\
\hline & 2 & Total years of work experience \\
\hline & 3 & Total years of experience in the current firm \\
\hline & 4 & Designation in the current firm \\
\hline & 5 & E-Mail ID (Optional) \\
\hline & 6 & Name of the Organization (Optional) \\
\hline \multirow{25}{*}{$\begin{array}{l}\text { Section } 2 \text { - } \\
\text { Environmental } \\
\text { Uncertainties } \\
\text { *Employee Skills } \\
\text { Related } \\
\text { Uncertainty } \\
\text { **Labour }^{\text {Demand and }} \\
\text { Supply } \\
\text { Uncertainty } \\
\left({ }^{*}, * * \text { are final }\right. \\
\text { scale items) }\end{array}$} & 1 & In our firm, the skills required by the employees undergo rapid change* \\
\hline & 2 & We, as employees, often need to learn new skills to match our job requirements* \\
\hline & 3 & Loss of human capital due to employee turnover (attrition) is high in our firm. \\
\hline & 4 & High employee turnover affects our current performance and future growth plans. \\
\hline & 5 & We need to constantly endeavour to maintain and improve our employee productivity* \\
\hline & 6 & $\begin{array}{l}\text { Our firm often faces shortages or surpluses of manpower due to fluctuations of demand of } \\
\text { our services** }\end{array}$ \\
\hline & 7 & $\begin{array}{l}\text { Due to market changes, we often have more, or less, number of employees compared to } \\
\text { the number required** }\end{array}$ \\
\hline & 8 & We often face significant competitive pressures to reduce our employment costs. \\
\hline & 9 & On the average, what percentage of total compensation of an employee is variable in nature? \\
\hline & 1 & $\begin{array}{l}\text { In my firm, people are recruited for their learning abilities rather than pure technical } \\
\text { skills* }\end{array}$ \\
\hline & 2 & $\begin{array}{l}\text { In my firm, those selection methods are used that help to detect employee flexibility and } \\
\text { adaptability* }\end{array}$ \\
\hline & 3 & $\begin{array}{l}\text { In my firm, adequate facilities are provided to employees for skill up-gradation and learning } \\
\text { new skills. }\end{array}$ \\
\hline & 4 & $\begin{array}{l}\text { The performance appraisal system in my organization closely tracks employee skill } \\
\text { development keeping in view their future needs* }\end{array}$ \\
\hline & 5 & $\begin{array}{l}\text { The promotion policy in my organization gives preference to employees with a superior } \\
\text { skill set* }\end{array}$ \\
\hline & 6 & The salary structure in my organization has a skill based pay component. \\
\hline & 7 & My firm offers monetary incentives and rewards for skill up-gradation or acquiring new skills. \\
\hline & 8 & My organization rarely recruits from outside (laterally) to meet the needs for new skills. \\
\hline & 9 & $\begin{array}{l}\text { The pay structure and financial benefit schemes in my organization reward employees with } \\
\text { longer tenure in the company. }\end{array}$ \\
\hline & 10 & $\begin{array}{l}\text { Employee attitude surveys are conducted regularly and the organization acts on their } \\
\text { findings** }\end{array}$ \\
\hline & 11 & $\begin{array}{l}\text { The jobs in my organization are designed to make them challenging and interesting for us } \\
\text { (employees). }\end{array}$ \\
\hline & 12 & We (employees) are regularly involved in decision making on job related matters** \\
\hline & 13 & $\begin{array}{l}\text { There is a well-working, formal employee grievance redressal system in my organization. } \\
* *\end{array}$ \\
\hline & 14 & $\begin{array}{l}\text { There is a vibrant employee suggestion scheme and my organization gets a significant } \\
\text { number of useful suggestions from us. ** }\end{array}$ \\
\hline & 15 & $\begin{array}{l}\text { Our Performance Appraisal system is flexible enough to accommodate changes in performance } \\
\text { parameters required due to changing business priorities. }\end{array}$ \\
\hline & 16 & We have an organization wide bonus plan that is linked to our firm/ division performance. \\
\hline
\end{tabular}




\begin{tabular}{|c|c|c|}
\hline & 17 & $\begin{array}{l}\text { Proper management of bench strength enables us to absorb the fluctuations of demand for } \\
\text { manpower effectively. }\end{array}$ \\
\hline & 18 & $\begin{array}{l}\text { Often task forces or temporary teams are created in my organization to respond to sudden } \\
\text { changes in customer demands. }\end{array}$ \\
\hline & 19 & $\begin{array}{l}\text { Our training facilities are adequate and scalable enough to meet sudden spurts in demand for } \\
\text { trained manpower. }\end{array}$ \\
\hline & 20 & $\begin{array}{l}\text { Team based working helps us to better respond to fluctuations of demand for our } \\
\text { products/services. }\end{array}$ \\
\hline & 21 & $\begin{array}{l}\text { In the recent years, there is a progressive increase in the variable component of our (employee) } \\
\text { compensation. }\end{array}$ \\
\hline \multirow{11}{*}{$\begin{array}{l}\text { Section } 4 \text { - Firm } \\
\text { Performance } \\
\text { * Relative } \\
\text { Performance } \\
* * \text { Performance } \\
\text { Improvement } \\
(*, * * \text { are final } \\
\text { scale items) }\end{array}$} & 1 & Growth of Sales Revenue* \\
\hline & 2 & Profitability (Profit/Sales)* \\
\hline & 3 & Operating Cost Efficiency (Total Cost/Sales)* \\
\hline & 4 & Growth of Market Share* \\
\hline & 5 & Overall Firm Performance* \\
\hline & 6 & Customer Satisfaction Level ${ }^{* *}$ \\
\hline & 7 & Efficiency of Operations** \\
\hline & 8 & Employee Productivity** \\
\hline & 9 & Ability to meet customer needs in terms of quality, cost and delivery schedule** \\
\hline & 10 & Successful launch of new product/service** \\
\hline & 11 & Ability to attract and retain customers** \\
\hline
\end{tabular}

\section{DATA AND METHODOLOGY}

\section{Sample}

A questionnaire based survey was conducted with employees in various firms/industries who are at middle management level and typically exposed to a diverse range of uncertainties. One limitation of this sample is that in a multi-industry context, firms in different industries face different types and levels of uncertainties. However, content and face validity during the start of this study ensured that the questionnaire instrument was generic to all industries and captures the uncertainties related to different industries. The selection criteria were based on the rationale that a) employees should be in a managerial position and $b$ ) respondents should be a part of the current firm for at least 6 months.

An e-mail request for participation in the study was sent to close to 200 employees across 5 sectors Management Consulting, Manufacturing, FMCG, IT and ITeS and Financial Services (See Figure 2). Relevant details about the nature of the study were furnished in the e-mails. A soft copy of the survey questionnaire was also attached to the e-mail. Reminder e-mails were sent after a gap of 15 days and this was followed by a second e-mail reminder after 30 days. Apart from e-mail reminders, telephonic contacts were also made to elicit response from the firms. Complete filled-in questionnaire responses could be obtained only from 56 respondents. This represented a response rate of about $28 \%$ which compared well with response rates achieved in similar studies in India (Singh, 2003) and abroad (Bhattacharya et al., 2005).

After testing for outliers, a final sample of 56 employees was used for further analysis. In the sample, employees (all post-graduates) had an overall work experience of 4.76 years and an average of 2.8 years in the current firm. The respondents were all junior/middle level managers at firms such as Aricent Technologies, Bank of India, IOCL, BPCL, ITC, Pepsi, Standard Chartered, Allegro Advisors, HUL, Microsoft, Cisco, Honda, Deloitte, Shell, HCL, Infosys etc. 


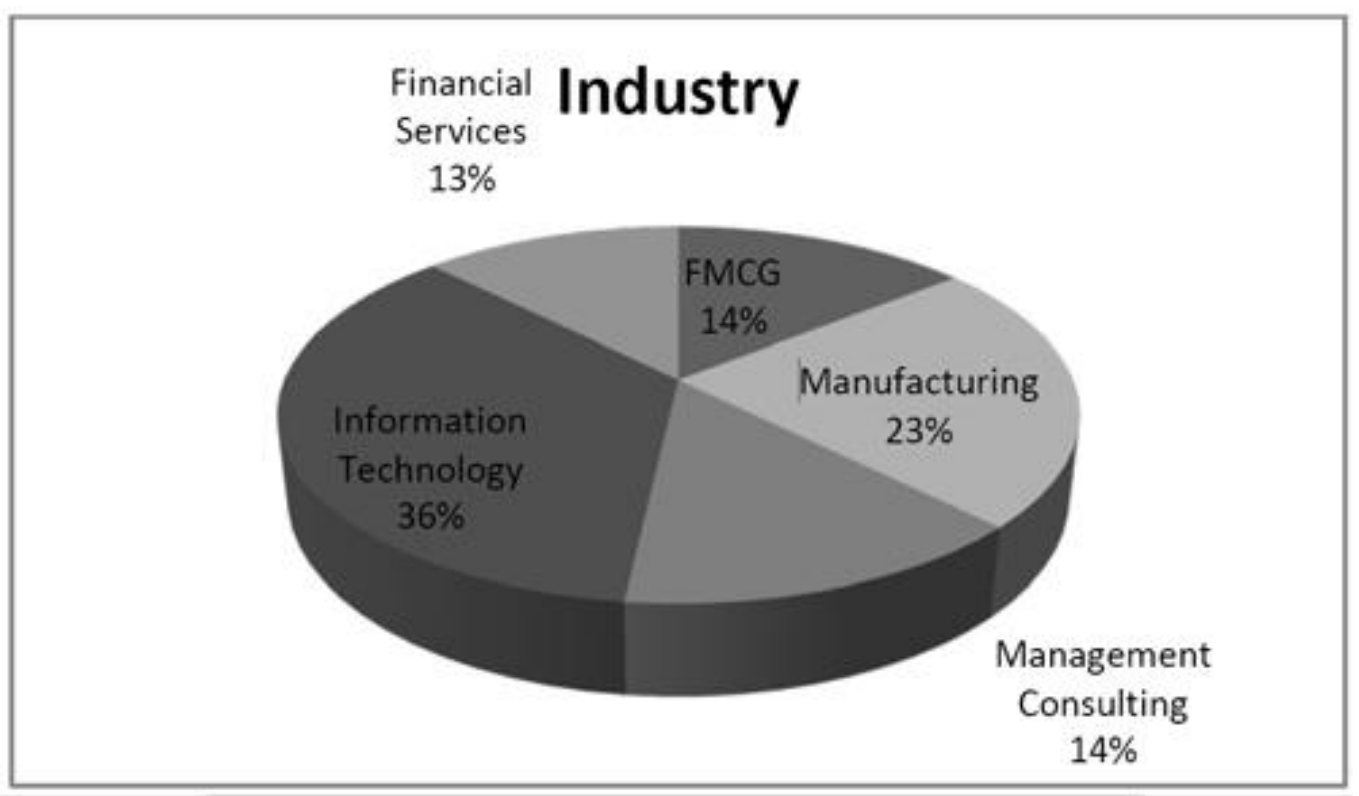

\section{Scales and Measures}

\section{Environmental Uncertainty}

The reliability (Cronbach Alpha) of the 8 item scale was 0.724 . Exploratory factor analysis (EFA) with Varimax rotation performed with 8 items revealed three factors. However, combinations of items of none of the factors that emerged were theoretically meaningful. Items which were not behaving well were, therefore dropped and only 5 items (A1, A2, A5, A6 and A7) were retained; the reliability dropped to 0.684 but revised factor structure neatly represented our two theoretical dimensions employee skills related uncertainty and labour demand supply uncertainty. The variance explained was $75.681 \%$ and the KMO measure of sampling adequacy was 0.626 at $1 \%$ significance level. The following table gives the construct descriptive statistics:

Table 2: Summary Item Statistics - Environmental Uncertainty

\begin{tabular}{|c|c|c|c|c|c|c|c|}
\hline & Mean & Minimum & $\begin{array}{c}\text { Maximu } \\
\mathrm{m}\end{array}$ & Range & $\begin{array}{c}\text { Maximum / } \\
\text { Minimum }\end{array}$ & Variance & $\begin{array}{c}\mathrm{N} \text { of } \\
\text { Items }\end{array}$ \\
\hline Item Means & 3.386 & 3.018 & 3.786 & .768 & 1.254 & .110 & 5 \\
\hline
\end{tabular}

\section{Human Resource Options}

The reliability (Cronbach Alpha) of the 21 item scale was 0.894. Exploratory factor analysis (EFA) with Varimax rotation performed with 21 items revealed six factors. However, combinations of items of none of the factors that emerged were theoretically meaningful. Items which were not behaving well were, therefore dropped and only 8 items (B1, B2, B4, B5, B10, B12, B13, B14) were retained; the reliability dropped to 0.776 but revised factor structure neatly represented our two theoretical dimensions - skill enhancement options and productivity enhance options. The variance explained was $57.854 \%$ and the KMO measure of sampling adequacy was 0.719 at $1 \%$ significance level. The following table gives the construct descriptive statistics:

Table 3: Summary Item Statistics - Human Resource Options

\begin{tabular}{|c|c|c|c|c|c|c|c|}
\hline & Mean & Minimum & $\begin{array}{c}\text { Maximu } \\
\mathrm{m}\end{array}$ & Range & $\begin{array}{c}\text { Maximum / } \\
\text { Minimum }\end{array}$ & Variance & $\begin{array}{c}\mathrm{N} \text { of } \\
\text { Items }\end{array}$ \\
\hline Item Means & 3.116 & 2.839 & 3.646 & .625 & 1.220 & .050 & 8 \\
\hline
\end{tabular}


Journal of Global Strategic Management | V. 6 | N. 2 | 2012-December | isma.info | 140-153 | DOI: 10.20460/JGSM.2012615781 Firm Performance

\section{Relative Performance}

The reliability (Cronbach Alpha) of the 5 item scale was 0.902. Exploratory factor analysis (EFA) with Varimax rotation performed with 21 items revealed only one factor. All five items were thus, a part of the final scale. The variance explained was $71.901 \%$ and the KMO measure of sampling adequacy was 0.813 at $1 \%$ significance level. The following table gives the construct descriptive statistics:

Table 4: Summary Item Statistics - Relative Performance

\begin{tabular}{|c|c|c|c|c|c|c|c|}
\hline & Mean & Minimum & $\begin{array}{c}\text { Maximu } \\
\mathrm{m}\end{array}$ & Range & $\begin{array}{c}\text { Maximum / } \\
\text { Minimum }\end{array}$ & Variance & $\begin{array}{c}\text { N of } \\
\text { Items }\end{array}$ \\
\hline Item Means & 3.364 & 3.125 & 3.625 & .500 & 1.160 & .037 & 5 \\
\hline
\end{tabular}

\section{Performance Improvement}

The reliability (Cronbach Alpha) of the 6 item scale was 0.863. Exploratory factor analysis (EFA) with Varimax rotation performed with 6 items revealed only one factor. All six items were thus, a part of the final scale. The variance explained was $59.606 \%$ and the KMO measure of sampling adequacy was 0.826 at $1 \%$ significance level. The following table gives the construct descriptive statistics:

Table 5: Summary Item Statistics - Performance Improvement

\begin{tabular}{|c|c|c|c|c|c|c|c|}
\hline & Mean & Minimum & Maximum & Range & $\begin{array}{c}\text { Maximum / } \\
\text { Minimum }\end{array}$ & Variance & $\begin{array}{c}\mathrm{N} \text { of } \\
\text { Items }\end{array}$ \\
\hline Item Means & 3.396 & 3.179 & 3.482 & .304 & 1.096 & .013 & 5 \\
\hline
\end{tabular}

\subsection{Results}

Table 6: Descriptive Statistics for all Measures

\begin{tabular}{|lcrrrrr|}
\hline & $\mathrm{N}$ & Minimum & Maximum & Mean & $\begin{array}{c}\text { Std. } \\
\text { Deviation }\end{array}$ \\
\hline $\begin{array}{l}\text { Employee Skills Related } \\
\text { Uncertainty }\end{array}$ & 56 & 1.33 & 5.00 & 3.54 & .94 \\
\hline $\begin{array}{l}\text { Labour Demand and Supply } \\
\text { Uncertainty }\end{array}$ & 56 & 1 & 5 & 3.15 & 1.09 \\
\hline Skills Enhancement Options & 56 & 1.00 & 5.00 & 3.29 & .80 \\
\hline Productivity Enhancement Options & 56 & 1.0 & 4.5 & 2.94 & .85 \\
\hline Relative Performance & 56 & 1.0 & 4.8 & 3.36 & .83 \\
\hline Performance Improvement & 56 & 1.83 & 4.83 & 3.39 & .72 \\
\hline Valid N (list-wise) & 56 & & & & \\
\hline
\end{tabular}

\section{Hypothesis Testing}

The first part of testing the hypothesis was to find out the strengths and direction of the relationships using correlation coefficients. The hypothesized key relationships have been highlighted. Employee skills related uncertainty is positively correlated to skills enhancement with a coefficient of $0.337^{*}$. This finding supports the results of prior studies. An interesting finding is the employee skills related uncertainty is positively correlated with firm performance. Both skills and productivity enhancement options have high positive correlation with the relative performance and performance improvement. Performance improvement is positively correlated to relative performance which can also be theoretically and cognitively explained. 
Table 7: Correlation Matrix

\begin{tabular}{|c|c|c|c|c|c|c|c|}
\hline & & $\begin{array}{c}\text { Employe } \\
\text { e Skills } \\
\text { Related } \\
\text { Uncertai } \\
\text { nty }\end{array}$ & $\begin{array}{c}\text { Labour } \\
\text { Demand } \\
\text { and } \\
\text { Supply } \\
\text { Uncertai } \\
\text { nty }\end{array}$ & $\begin{array}{c}\text { Skills } \\
\text { Enhanceme } \\
\text { nt Options }\end{array}$ & $\begin{array}{l}\text { Productivi } \\
\text { ty } \\
\text { Enhancem } \\
\text { ent } \\
\text { Options }\end{array}$ & $\begin{array}{c}\text { Relative } \\
\text { Performance }\end{array}$ & $\begin{array}{l}\text { Performance } \\
\text { Improvement }\end{array}$ \\
\hline $\begin{array}{l}\text { Employee } \\
\text { Skills } \\
\text { Related } \\
\text { Uncertainty }\end{array}$ & $\begin{array}{l}\text { Pearson } \\
\text { Correlation } \\
\text { Sig. (2-tailed) }\end{array}$ & 1 & $\begin{array}{l}.146 \\
.282\end{array}$ & $\begin{array}{r}.337 \\
.011\end{array}$ & $\begin{array}{l}.181 \\
.182\end{array}$ & $\begin{array}{r}.353 \\
.008\end{array}$ & $\begin{array}{l}.283 \\
.034\end{array}$ \\
\hline $\begin{array}{l}\text { Labour } \\
\text { Demand and } \\
\text { Supply } \\
\text { Uncertainty }\end{array}$ & $\begin{array}{l}\text { Pearson } \\
\text { Correlation } \\
\text { Sig. (2-tailed) }\end{array}$ & $\begin{array}{l}.146 \\
.282\end{array}$ & 1 & $\begin{array}{l}.104 \\
.446\end{array}$ & $\begin{array}{l}.131 \\
.337\end{array}$ & $\begin{array}{l}.146 \\
.284\end{array}$ & $\begin{array}{l}.078 \\
.567\end{array}$ \\
\hline \begin{tabular}{|l|} 
Skills \\
Enhanceme \\
nt Options
\end{tabular} & $\begin{array}{l}\text { Pearson } \\
\text { Correlation } \\
\text { Sig. (2-tailed) }\end{array}$ & $\begin{array}{l}.337^{*} \\
.011\end{array}$ & $\begin{array}{l}.104 \\
.446\end{array}$ & 1 & $\begin{array}{r}.375^{* 7} \\
.004\end{array}$ & $\begin{array}{r}.447^{7 x} \\
.001\end{array}$ & $\begin{array}{l}. \mathbf{4 4 2} \\
.001\end{array}$ \\
\hline $\begin{array}{l}\text { Productivity } \\
\text { Enhanceme } \\
\text { nt Options }\end{array}$ & $\begin{array}{l}\text { Pearson } \\
\text { Correlation } \\
\text { Sig. (2-tailed) }\end{array}$ & $\begin{array}{l}.181 \\
.182\end{array}$ & $\begin{array}{l}.131 \\
.337\end{array}$ & $\begin{array}{l}.375^{\circ 0} \\
.004\end{array}$ & 1 & $\begin{array}{r}.538^{\text {*7 }} \\
.000\end{array}$ & $\begin{array}{l}.499^{27} \\
.000\end{array}$ \\
\hline \begin{tabular}{|l|} 
Relative \\
Performanc \\
e
\end{tabular} & $\begin{array}{l}\text { Pearson } \\
\text { Correlation } \\
\text { Sig. (2-tailed) }\end{array}$ & $\begin{array}{l}.353^{20} \\
.008\end{array}$ & $\begin{array}{l}.146 \\
.284\end{array}$ & $\begin{array}{l}.447^{+2} \\
.001\end{array}$ & $\begin{array}{l}.538^{\circ+1} \\
.000\end{array}$ & 1 & $\begin{array}{r}.425^{2 \pi} \\
.001\end{array}$ \\
\hline $\begin{array}{l}\text { Performanc } \\
\text { e } \\
\text { Improvemen } \\
\text { t }\end{array}$ & $\begin{array}{l}\text { Pearson } \\
\text { Correlation } \\
\text { Sig. (2-tailed) }\end{array}$ & $\begin{array}{l}.283^{n} \\
.034\end{array}$ & .078 & $\begin{array}{l}.442^{+4} \\
.001\end{array}$ & $\begin{array}{l}.499^{\circ+2} \\
.000\end{array}$ & $\begin{array}{r}.425^{* 7} \\
.001\end{array}$ & 1 \\
\hline
\end{tabular}

. Correlation is significant at the 0.05 level (2-tailed)

**. Correlation is significant at the 0.01 level (2-tailed).

The spline curve in Figure 3 supports hypothesis 2 . As human resource option value increases, the firm's performance improve is the perception of the employees. A simple test of mean values of firm performance for low (<3), medium (3-4) and high (>4) values of human resource options, the firm performance showed values: $2.93,3.68$ and 4.18 respectively. Thus, employees perceive the positive effect of using HR option on firm performance.

\section{Figure 3: Cubic Spline Curve between Firm Performance and Human Resource Options}

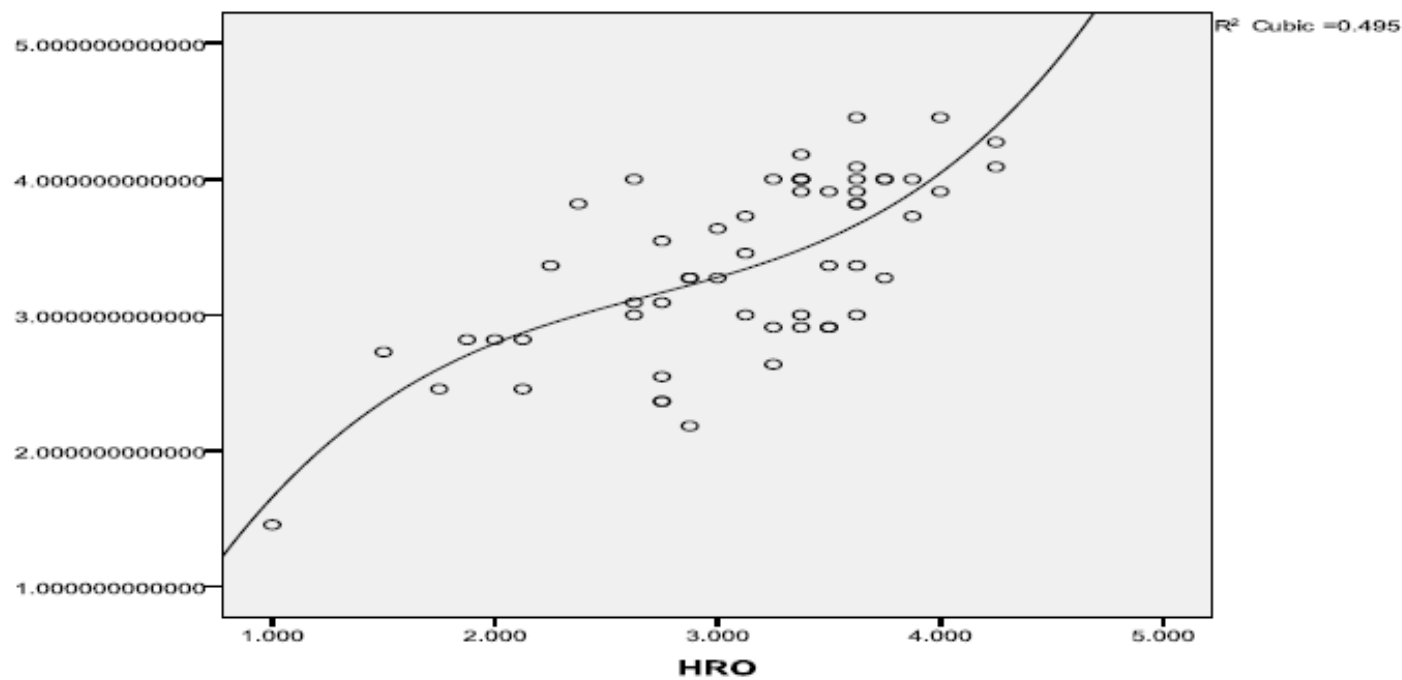

For testing the mediated relationship as hypothesised (Hypothesis 1), procedure was followed as suggested in Baron and Kenny 1986; Mackinnon \& Dwyer, 1993. The following table gives the 
Journal of Global Strategic Management | V. 6 | N. 2 | 2012-December | isma.info | 140-153 | DOI: 10.20460/JGSM.2012615781 hierarchical regression results. Further, to estimate the strength of mediation, Sobel's Test statistic (Sobel, 1982) was calculated for the mediated model. The results show that Human resource options mediate the relationship between environmental uncertainty and firm performance. The indirect effect and significance value of this partial mediation relationship are 0.1707 and 0.0269 .

\section{Table 8:Hierarchical Regression Results}

\begin{tabular}{|c|c|c|}
\hline \multirow{2}{*}{$\begin{array}{c}\text { Hierarchical } \\
\text { Regression } \\
\text { Results }\end{array}$} & \multicolumn{2}{|c|}{ Firm Performance } \\
\hline & Model 1 & Model 2 \\
\hline $\begin{array}{c}\text { Environmental } \\
\text { Uncertainty }\end{array}$ & $\begin{array}{l}0.354^{* *} \\
(0.109)\end{array}$ & $\begin{array}{c}0.155 \\
(0.088)\end{array}$ \\
\hline $\begin{array}{c}\text { Human } \\
\text { Resource } \\
\text { Options }\end{array}$ & - & $\begin{array}{c}0.641 \text { *** } \\
(0.097)\end{array}$ \\
\hline $\begin{array}{l}\text { Adjusted R- } \\
\text { Square }\end{array}$ & 0.109 & 0.477 \\
\hline
\end{tabular}

VARIABLES IN SIMPLE MEDIATION MODEL

Y Firm Performance (FP)

X Environmental Uncertainty (EU)

M Human Resource Options (HRO)

DESCRIPTIVES STATISTICS AND PEARSON CORRELATIONS

$\begin{array}{lrrrrr} & \text { Mean } & \text { SD } & \text { FP } & \text { EU } & \text { HRO } \\ \text { FP } & 3.3815 & .6534 & 1.0000 & .3537 & .6889 \\ \text { EU } & 3.3857 & .7607 & .3537 & 1.0000 & .3101 \\ \text { HRO } & 3.1161 & .6912 & .6889 & .3101 & 1.0000\end{array}$

SAMPLE SIZE

56

\section{DIRECT AND TOTAL EFFECTS}

$\begin{array}{lrrrr} & \text { Coeff. } & \text { s.e. } & \mathrm{t} & \text { Sig(two) } \\ \mathrm{b}(\text { YX) } & .3038 & .1093 & 2.7788 & .0075 \\ \mathrm{~b}(\mathrm{MX}) & .2818 & .1176 & 2.3969 & .0200 \\ \mathrm{~b}(\text { YM.X) } & .6058 & .0969 & 6.249 & 7.0000 \\ \mathrm{~b}(\text { YX.M) } & .1331 & .0881 & 1.511 & 3.1366\end{array}$

INDIRECT EFFECT AND SIGNIFICANCE USING NORMAL DISTRIBUTION

$\begin{array}{rrrrrrr} & \text { Value } & \text { s. e. } & \text { LL95CI } & \text { UL95CI } & \text { Z } & \text { Sig(two) } \\ \text { Effect } & \mathbf{. 1 7 0 7} & .0771 & .0195 & .3218 & 2.2134 & \mathbf{. 0 2 6 9}\end{array}$


Journal of Global Strategic Management | V. 6 | N. 2 | 2012-December | isma.info | 140-153 | DOI: 10.20460/JGSM.2012615781

BOOTSTRAP RESULTS FOR INDIRECT EFFECT

$\begin{array}{rrrrrrrr} & \text { Data } & \text { Mean } & \text { s.e. } & \text { LL99CI } & \text { LL95CI } & \text { UL95CI } & \text { UL99CI } \\ \text { Effect . } & 1707 & .1711 & .1005 & -.0827 & -.0113 & .3834 & .4762\end{array}$

NUMBER OF BOOTSTRAP RESAMPLES

1000

POINT AND INTERVAL ESTIMATES OF EFFECT SIZE FOR INDIRECT EFFECT

$\begin{array}{lrrrrrrr} & \text { Data } & \text { Mean } & \text { s.e. } & \text { LL99CI } & \text { LL95CI } & \text { UL95CI } & \text { UL99CI } \\ \text { ab } & .1707 & .1711 & .1005 & -.0827 & -.0113 & .3834 & .4762 \\ \text { P_m } & .5618 & .6574 & 1.6023 & -1.0500 & -.0131 & 1.4108 & 6.2226 \\ \text { R_m } & 1.2823 & 6.8535 & 192.3758 & -83.1096 & -12.3880 & 9.4563 & 47.3457 \\ \text { R2_45 } & .1034 & .1105 & .0830 & -.0216 & -.0040 & .3005 & .3608 \\ \text { ab_ps } & .2612 & .2581 & .1410 & -.1335 & -.0171 & .5414 & .6114 \\ \text { ab_cs } & .1987 & .1947 & .1084 & -.0965 & -.0121 & .4189 & .4757\end{array}$

\section{DISCUSSION AND CONCLUSION}

The present study hopes to make three important contributions to the literature. First, it refines the earlier conceptualization of HR options made by Sanyal and Sett (2009) and then operationalizes it in terms of specific HR practices deployed by the firms to manage the uncertainties faced by their human assets. Second, it empirically investigates the mediating linkage between use of HR options on the relationship between environmental uncertainties and firm's operational and financial performance. The third and according to the researchers, the most interesting insight from this study is that the above two investigations are true as per the middle managers, an aspect that has not been studied so far. This new perspective is likely to deepen the knowledge of managers on how to manage human resources and make investments on human assets to create an organizational capability that helps their firms to achieve sustainable competitive advantage in a dynamic environment. The cross-sectional nature of the study is its major limitation. There is expected to be an inevitable time lag between adoption of a HR practice and before its results start showing up (Wright, Gardner, Moynihan, \& Allen, 2005). This study does not take such temporal factors into account. Future research based on panel data or cross-sectional studies conducted in phases may lead to further refinements of the findings. Moreover, the small size of the sample is also a limitation of the study; however, the sample is representative of different sectors and is therefore generalizable. 


\section{REFERENCES}

Amram, M., and Kulatilaka, N. (1999) Real Options: Managing Strategic Investment in an Uncertain World. Boston. MA: Harvard Business School Press.

Arthur, J.B. (1994) 'Effects Of Human Resource Systems on Manufacturing Performance and Turnover', Academy of Management Journal, 37 (3): 670-87.

Atkinson, J. 1984. 'Manpower Strategies for Flexible Organizations', Personnel Management, 16: 2831.

Becker, B. E. and Huselid, M. A. (1998) 'High Performance Work Systems and Firm Performance: A Synthesis of Research and Managerial Implications'. In Ferris, G.R. (ed.), Research in Personnel and Human Resources Management. Vol. 16. Greenwich, CT: JAI Press, pp. 53-101.

Bhattacharya, M., and Wright, P.M. (2005), 'Managing Human Assets in an Uncertain

World: Applying Real Options Theory to HRM,' International Journal of Human

Resource Management, 16, 6, 929-948.

Black, E. and Scholes, M. (1973) 'The pricing of options and corporate liabilities', Journal of Political Economy, 81: 637-659.

Bowman, E.H. and Hurry, D. (1993) 'Strategy through the option lens: An integrated view of resource investments and the incremental choice process', Academy of Management Review, 18(4): 760782.

Dixit, A. and Pindyck, R. (1994) Investment under Uncertainty. Princeton. NJ: Princeton University Press.

Eisenhardt K, Martin J. 2000. Dynamic capabilities: what are they? Strategic Management Journal, October-November Special Issue 21: 1105-1121.

Huselid, M.A. 1995, The impact of human resource management practices on turnover, productivity and corporate financial performance. Academy of management Journal, 38: 635 -672

Kogut, B and Kulatilaka, N. (2001), 'Capabilities as Real Options', Organization Science, Vol. 12, No. 6 (Nov. - Dec., 2001), pp. 744-758

Lepak, D.P. and Snell, S.A. (2002) 'Examining the human resource architecture: The relationships among human capital, employment, and human resource configurations', Journal of Management, 28(4): 517-543.

MacDuffie, J. P. 1995. Human resource bundles and manufacturing performance:

Organizational logic and flexible production systems in the world of auto industry.

Industrial and Labor Relations Review, 48: 197221.

McGrath, R.G., Ferrier, W.J. and Mendelow, A.L. (2004) 'Response: Real Options as Engines of Choice and Heterogeneity', Academy of Management Review, 29(1): 86-101.

Myers, S.C. (1977) 'Determinants of corporate borrowing', Journal of Financial Economics. 5: $147-$ 176.

Myers, S.C. (1984) 'Financial theory and firm strategy’, Interfaces, 14(1): 126-137.

Pfeffer, J. (1995), 'Producing Sustainable Competitive Advantage through Effective Management of People,' Academy of Management Executive, 9, 1, 55-72.

Raisch, S. and Birkinshaw, J. (2008) 'Organizational Ambidexterity: Antecedents, Outcomes, and Moderators', Journal of Management, 34(3): 375-409.

Sanyal, S. and Sett, P.K. (2009), 'Applying real options theory to HRM: an empirical study of IT software firms in India (IJHRM Reference No. 1908) 


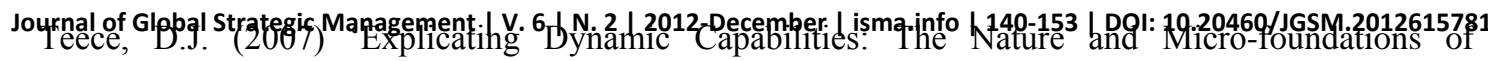
(Sustainable) Enterprise Performance', Strategic Management Journal, 28: 1319-1350.

Teece, D. J., Pisano, G. and Shuen, A. (1997) 'Dynamic Capabilities and Strategic Management', Strategic Management Journal, 18(7): 509-33.

Trigeorgis, L. (1993) 'The nature of option interactions and the valuation of investments with multiple real options', Journal of Financial and Quantitative Analysis, 28(1): 1-20.

Trigeorgis, L. (2001) 'Real Options: An Overview'. In Schwartz, E.S. and Trigeorgis, L. (Eds) Real options and investment under uncertainty: classical readings and recent contributions. Cambridge, MA: MIT Press.

Wright, P. M. and Snell, S. A. (1998) 'Toward a Unifying Framework for Exploring Fit and Flexibility in Strategic Human Resource Management', Academy of Management Review, 23(4): 756-72.

Youndt, M., Snell, S.A., Dean, J.W., Jr. and Lepak, D.P. (1996) 'Human Resource Management, Manufacturing Strategy, and Firm Performance', Academy of Management Journal, 39(4): 836-66. 